\title{
AL-QUR'AN DAN PLURALITAS: Membangun Kehidupan Masyarakat yang Majemuk
}

\author{
Abd. Rahman I. Marasabessy \\ Sekolah Tinggi Agama Islam Negeri Ternate \\ J1. Lumba-Lumba Kelurahan Dufa-Dufa, Ternate, Maluku Utara, 97727 \\ e-mail: abdurman@rocketmail.com
}

\begin{abstract}
Abstrak: Tulisan ini mengkaji konsep pluralisme agama sebagaimana terdapat dalam ayat-ayat al-Qur'an. Semua agama-agama di dunia pada waktu tertentu telah takluk kepada tekanan sekuler dan menundukkan pesan moral-spiritual utama di bawah ambisi politis dan interest komunitas khusus mereka. Al-Qur'an menginformasikan bahwa pluralisme agama merupakan sesuatu yang alami (sunnah Allâh), dan manusia diciptakan dalam pluralitas, bahkan jika Tuhan menghendaki, tentu Dia menjadikan manusia umat yang satu, sekalipun secara faktual tidak demikian. Penulis menemukan bahwa pluralisme agama dalam al-Qur'an, bukan saja untuk memberikan kahidupan yang layak intern umat Islam, tetapi lebih dari itu memberikan semangat hidup berdampingan dengan umat lainnya, baik dalam kehidupan keagamaan, kebangsaan, dan kehidupan antar bangsa.
\end{abstract}

\begin{abstract}
Al-Qur'an and Plurality: Building Heterogeneous Social Lives. This article studies the pluralism related concepts according to the verses of the Qur'an. All the world religions at a certain time had overruled by secular pressure and had controlled the fundamentals of moral-spiritual message for the sake of the political ambition and interest of their certain communities. The Qur'an informs that religious pluralism is something natural, and humankind is created in plurality, and even if God so Will, He should have created man in a single community, although this is contrary to the fact. The author finds that pluralism according to the Qur'an, does not only cater the proper Muslim lives internally, but, above all, also provide for the spirit of living together with other community both in matters of religious, national and international lives.
\end{abstract}

Kata Kunci: pluralitas, al-Qur'an, masyarakat majemuk

\section{Pendahuluan}

Agama memiliki peran yang sangat strategis dalam mempertahankan posisi manusia supaya tidak jatuh ke tingkat yang lebih rendah sesuai dengan fitrah manusia 
potensial dan energik luar biasa yang memungkinkan dikembangkan atau menjadi sesuatu yang tidak berarti bagi manusia itu sendiri.

Kehidupan manusia pada era globalisasi dan teknologi informasi modern yang semakin maju dan menjangkau seluruh lapisan masyarakat, bahkan batas-batas wilayah, maka manusia dihadapkan kepada serangkaian tantangan baru seperti bebas mengeluarkan pendapat, keterbukaan dan demokratisasi. Hal tersebut membuktikan bahwa bangsa Indonesia telah ditakdirkan hidup dalam suatu bangsa yang masyarakatnya dapat dikatakan sangat pluralistik, ${ }^{1}$ bahkan di kalangan bangsa-bangsa lain dinilai sebagai keunikan dan penanganannya pun memerlukan keunikan. Pandangan lain dikatakan bahwa pluralisme bukanlah keunikan suatu masyarakat atau bangsa tertentu. Sebab dalam kenyataan tidak ada suatu masyarakat pun yang benar-benar tunggal, tanpa ada perbedaan di dalamnya.

Kemajemukan sebagai suatu realitas alami yang dalam bahasa agama disebut sunnah Allâh, ${ }^{2}$ tetapi apapun namanya, manusia dalam perkembangannya tidak bisa melepaskan diri dari lingkungan pergaulan yang dimungkinkan untuk terjadinya pengaruh, sehingga dapat dilihat manusia telah tererosi oleh perkembangan pemikiran dan kebudayaan, atas nama memenuhi kebutuhan hidup manusia, sebagaimana telah diperingatkan oleh Allah SWT. bahwa telah terjadi kerusakan di darat dan di laut akibat ulah tangan-tangan manusia. ${ }^{3}$

Pluralisme tidak hanya semata menunjuk kepada kenyataan adanya kemajemukan, tetapi juga keterlibatan aktif terhadap kenyataan kemajemukan. Dalam tiga dekade terakhir, agama muncul sebagai sumber penting imperatif moral yang diperlukan untuk memelihara kohesi sosial. Komitmen religius tidak sekedar memobilisasi rasa amarah rakyat dalam melawan kekuatan otokratis negara, melainkan juga memainkan peranan konstruktif dalam pembangunan bangsa dan rekonsiliasi nasional. ${ }^{4}$ Pluralisme agama dapat dijumpai di mana-mana, baik di tingkat regional, nasional terlebih dalam pergaulan internasional, yang dapat dilihat di dalam kehidupan keluarga, masyarakat, perkantoran tempat bekerja, dan di sekolah tempat belajar. Setiap pemeluk agama dituntut untuk

${ }^{1}$ Masyarakat Indonesia biasa diidentifikasi sebagai masyarakat majemuk (plural) dalam kenyataan tidak jarang terselip kesan, seolah-olah kemajemukan masyarakat adalah suatu keunikan di kalangan masyarakat lain. Karena keunikannya, maka masyarakat memerlukan perlakuan yang unik pula yaitu, perlakuan berdasarkan paham kemajemukan pluralisme. Lihat Nurcholish Madjid, Islam Doktrin dan Peradaban (Jakarta: Yayasan Wakaf Paramadina, 1992), h. 159.

${ }^{2}$ Nurcholish Madjid berpandangan bahwa sistem nilai plural adalah sebuah aturan Tuhan yang tidak mungkin berubah, diubah, dilawan, dan diingkari, karena barangsiapa yang mengingkari hukum kemajemukan budaya, maka akan timbul fenomena pergolakan yang tiada berkesudahan. Lihat, M. Quraish Shihab, et al. Atas Nama Agama Wacana Agama dalam Dialog Bebas Konflik (Bandung: Pustaka Hidayah, 1998), h. 66.

${ }^{3}$ Q.S. al-Rûm/30: 41

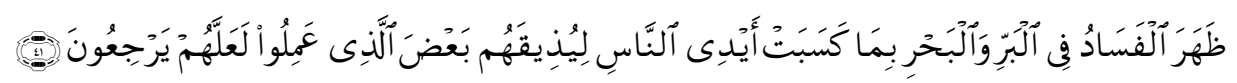

${ }^{4}$ Abdulaziz Sachedina, Kesetaraan Kaum Beriman: Akar Pluralisme Demokratis dalam Islam, terj. Satrio Wahono (Jakarta: Serambi Ilmu Semesta, 2002), h. 17. 
tidak saja mengakui keberadaan dan hak agama lain, tetapi juga berusaha mengalami dan memahami perbedaan dan persamaan untuk terciptanya kerukunan dalam kebinekaan. Hal ini sebagaimana digambarkan al-Qur'ân:

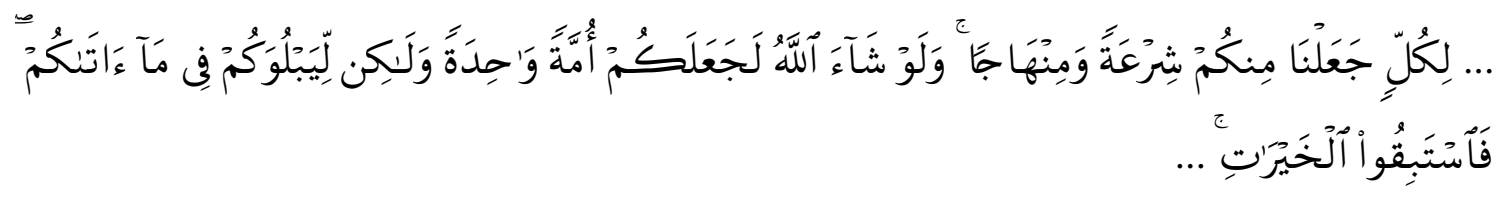

Tiap-tiap umat di antara kamu, Kami berikan aturan dan jalan yang terang, sekiranya Allah menghendaki, niscaya kamu dijadikan-Nya umat yang satu, tetapi Allah hendak menguji terhadap pemberian-Nya kepadamu, maka berlomba-lombalah berbuat kebajikan(Q.S. alMâ'idah/5: 48).

\section{Pengertian Pluralisme}

Pluralisme berasal dari kata 'plural' yang bermakna banyak, lebih dari satu 'pluralis' bersifat jamak. Pluralisme sebagai hal yang menyatakan jamak atau tidak satu, seperti dapat dikatakan pluralisme kebudayaan bermakna sebagai kebudayaan yang berbedabeda di suatu masyarakat. ${ }^{5}$ Pluralisme adalah ajaran bahwa kenyataan berdasarkan asas masing-masing kelompok tidak berhubungan satu dengan yang lain, bahwa kenyataan (realitas) terdiri dari berbagai unsur dasar yang masing-masing berlainan tampak pada lahirnya, tetapi bila dikaji lebih mendalam tidak berbeda secara hakikat dan esensi pada satu satu kelompok dengan kelompok yang lain. Penganut pluralisme yang terkenal antara lain Leibniz. ${ }^{6}$ Dalam Encyclopedia Americana disebutkan:

Pluralism: Ploor al-iz'm, in Philosophy. The view that the world consists of many beings, It is genarally contrasted with monism in which things all manifest just one substance or principle, and to dualism in which they manifest just twoo. The plurality which it emphasizes may bi the numerical distinectness of individuals-physical atoms, as in ancient materialism, and the extreme realism of Johanan Fried rich Hubart (1776-1841) Spiritual Units, as in the monadism of Gottfried Wilhelm Leibnez (1645-1716) and the more recent personal idealism or event and processes, in William James (1842-1910) and Alfred North White head (1863-1947). But its emphasis also may bi on differences in some ancient pluralism-that of Anaxagoras (500?-428 B.c) for instance, in the philosophy of William James; and in most modern naturalisms. The latter form of pluralism specially asserts the reality of the individual, of change and for canflict and for progress. Atomism and monadism are Sometism. ${ }^{7}$

Istilah pluralisme merupakan salah satu kata ringkas untuk menyebut satu tatanan

${ }^{5}$ Depdiknas, Kamus Besar Bahasa Indonesia (Jakarta: Balai Pustaka, 1990), h. 691.

${ }^{6}$ Ensiklopedi Indonesia, Vol. V (Jakarta: Ichtiar Baru Van Hoeve, 1984), h. 2727.

${ }^{7}$ Encyclopedia Americana, Jilid XXII (Philippines: Copy right, 1972), h. 258-259. 
dunia baru di mana perbedaan budaya, sistem kepercayaan, dan nilai-nilai membangkitkan bergairahnya pelbagai ungkapan manusia yang tidak kunjung habis sekaligus mengilhami konflik yang tidak terdamaikan. Menyebut kata pluralisme telah menjadi semacam panggilan untuk hari raya, suatu seruan untuk warga negara dunia untuk berdamai dengan perbedaan mereka yang memusingkan. Konflik abadi antara Kristen dan Muslim, Hindu dan Sikh, Tamil dan Buddha, dan kekejaman terhadap warga negara tidak berdosa, semuanya mendesak adanya imperatif moral yang mengakui martabat kemanusiaan orang lain tanpa memandang agama, suku, dan afiliasi kulturalnya. ${ }^{8}$

Filsafat Pluralisme adalah ajaran yang menekankan pada kenyataan berdasarkan berbagai asas masing-masing, tidak berhubungan yang satu dengan yang lain, bahwa kenyataan (realitas) terdiri dari berbagai unsur dasar, masing-masing berlainan hakikat pada yang satu dengan yang lain. Dalam ilmu negara dinyatakan bahwa kekuasaan pemerintah di suatu negara harus dibagi-bagikan antara berbagai golongan karyawan dan tidak dibenarkan adanya monopoli suatu golongan. Tokoh terkemuka teori ini adalah Harold J. Leski, A. D. Lisdsay dan Lion Dugnet. ${ }^{9}$

Pengertian pluralisme secara operasional dapat dinyatakan sebagai berikut. Pertama. Pluralism tidak semata menunjuk pada kenyataan adanya kemajemukan. Namun yang dimaksud adalah keterlibatan aktif terhadap kenyataan kemajemukan tersebut. Pluralisme agama dapat dijumpai di mana-mana. Pluralisme agama menuntut pada setiap pemeluk agama mengakui keberadaan dan hak agama lain, tetapi berusaha memahami persamaan dan perbedaan, guna tercapainya kerukunan dalam kebinekaan yang sungguh-sungguh. Bahwa pluralisme harus dapat terpahami oleh masyarakat dunia, sebagai sesuatu yang tidak bisa dihindari dalam pergaulan manusia.

Kedua, pluralisme harus dibedakan dengan kosmopolitanisme, karena kosmopolitanisme menunjuk pada suatu realitas di mana aneka ragama agama, ras, bangsa hidup berdampingan di suatu lokasi. ${ }^{10}$

Ketiga, pluralisme tidak bisa disamakan dengan relativisme. Karena seorang relativis akan berasumsi bahwa hal-hal yang menyangkut kebenaran atau nilai tertentu oleh pandangan hidup serta kerangka berpikir seseorang atau masyarakat. Sebagai konsekuensi dari paham relativisme agama, doktrin agama apapun harus dinyatakan benar. Hanya saja kebenarannya relatif. Pengakuan terhadap pluralisme agama dalam suatu komunitas umat beragama menjanjikan dikedepankannya prinsip inklusivisme, suatu prinsip yang

${ }^{8}$ Sachedina, Kesetaraan Kaum Beriman, h. 48.

${ }^{9}$ Ensiklopedi Indonesia, h. 2727.

${ }^{10}$ Dapat dicontohkan kota New York. Kota ini adalah kota kosmopolitan, di kota ini terdapat komunitas Yahudi, Kristen, Muslim, Hindu, Buddha, bahkan orang-orang yang tanpa agama sekalipun. Seakan seluruh penduduk dunia berada di kota ini. Namun interaksi positif antar penduduk, khususnya di bidang agama begitu baik. Alwi Shihab, Islam Inklusif Menuju Sikap Terbuka dalam Beragama (Bandung: Mizan, 2001), h. 41. 
mengutamakan akomodasi dan bukan konflik di antara berbagai klaim kebenaran agama dalam masyarakat yang heterogen secara kultural dan religius. Inklusivitas semacam itu bermuara pada tumbuhnya kepekaan terhadap berbagai kemungkinan unik yang bisa memperkaya usaha manusia dalam mencari kesejahteraan spiritual dan moral. ${ }^{11}$ Kebenaran agama-agama walaupun berbeda dan bertentangan satu sama lainnya, tetapi harus diterima. Untuk itu, seorang relativis tidak akan mengenal apalagi menerima suatu kebenaran universal yang berlaku untuk semua dan sepanjang masa. Tidak dapat dimungkiri bahwa dalam paham pluralisme terdapat unsur relativisme, yakni unsur tidak mengklaim pemilikan tunggal (monopoli) atas suatu kebenaran, apalagi memaksakan kebenaran kepada pihak lain. Paling tidak seorang pluralis akan menghindari sikap absolutisme yang menonjolkan keunggulannya terhadap pihak lain. ${ }^{12}$ Berusaha untuk merendahkan selainnya, karena hal tersebut bertentangan dengan prinsip pluralisme.

Keempat, pluralisme agama bukanlah sinkretisme, yaitu menciptakan agama baru dengan memadukan unsur tertentu atau sebagian komponen ajaran dari beberapa agama untuk dijadikan bagian integral dari agama baru tersebut. Pluralisme bermakna menyatakan jamak sedangkan agama bermakna kepercayaan kepada Allah SWT., Tuhan Yang Maha Esa dan pencipta seluruh alam raya. Agama yang benar di Sisi Tuhan Yang Maha Esa ialah sikap pasrah dan tulus kepada-Nya. ${ }^{13}$ Pertanyaan yang dapat dikemukakan adalah apakah semua agama samawi, yakni Yahudi, Nasrani dan Islam memiliki sikap pasrah kepada Tuhan Yang Maha Esa.

\section{Pluralitas dalam al-Qur'an}

Al-Qur'an sebagai kitab suci umat Islam diyakini sebagai sumber ajaran sekaligus pedoman hidup bagi setiap Muslim dalam melakukan berbagai aktifitas, baik ibadah kepada Allah SWT. maupun hubungan sesama manusia yang menjadi inti diwahyukannya alQur'an kepada Nabi Muhammad SAW. untuk melanjutkan ajaran para nabi sebelumnya, mengatur hubungan yang saling menghargai dan menerima sesama umat manusia penghuni bumi, bahkan seluruh makhluk ciptaan Tuhan yang juga bagian dari penghuni bumi. AlQur'an dapat memberikan cahaya bagi yang membaca, menelaah dan mengamalkannya.

${ }^{11}$ Sachedina, Kesetaraan Kaum Beriman, h. 49.

${ }^{12}$ Syihab, Islam Inklusif, h. 42.

${ }^{13}$ Pasrah kepada Tuhan adalah sikap batin yang sifatnya perorangan, maka dari sudut kenyataan hanyalah yang bersangkutan sajalah selain Tuhan yang benar-benar mengetahui apakah ia secara sejati pasrah kepada Tuhan atau tidak. Pandangan dasar ini menjadi salah satu landasan bahwa agama yang benar tidak mengakui adanya pelimpahan beban seseorang pribadi manusia kepada seorang pribadi dalam berhubungan dengan Tuhan. Sebaliknya, agama yang benar menegaskan hubungan antara seorang hamba dengan Tuhannya. Madjid, Islam Doktrin dan Peradaban, h. 345. 
Persoalan yang dihadapi oleh manusia mengungkap makna al-Qur'an adalah hermeneutika. ${ }^{14}$

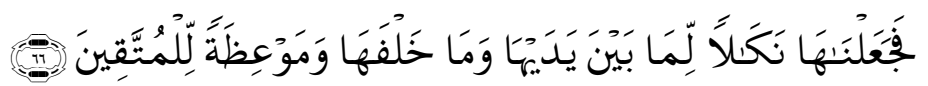

Maka Kami jadikan yang demikian itu peringatan bagi orang-orang di masa itu, dan bagi mereka yang datang kemudian, serta menjadi pelajaran bagi orang-orang yang bertakwa. (Q.S. al-Baqarah/2: 66)

Ayat tersebut mengingatkan manusia agar taat kepada Allah dan tidak melanggar ketentuan-ketentuan yang telah disampaikan kepada umat manusia lewat kitab suci yang telah disampaikan kepada Nabi Muhammad SAW. Supaya manusia selalu mendekatkan diri kepada Allah SWT. dan senantiasa berusaha menjadi orang-orang yang bertakwa. Kata mau'izhah (nasehat), yaitu sebagai petunjuk peringatan yang melembutkan hati sehingga orang kembali sadar dari perbuatannya yang salah. ${ }^{15}$ Kata ini disebut 9 kali dalam al-Qur'an, di antaranya dapat dilihat pada Q.S. Yûnus/10: 57, Q.S. Hûd/11: 120 dan Q.S. al-Nûr/24: 34.

Kendati al-Qur'an, pada dasarnya adalah kitab keagamaan, namun pembicaraanpembicaraannya dan kandungan isinya tidak terbatas pada bidang-bidang keagamaan semata, tetapi meliputi berbagai aspek kehidupan manusia. Pembahasan al-Qur'an terhadap berbagai aspek atau masalah tidak tersusun secara sistematis, sebagaimana layaknya sebuah buku ilmiyah, al-Qur'an jarang menginformasikan suatu masalah secara rinci, tetapi cenderung parsial dan global, lebih pada prinsip-prinsip pokok. Hal tersebut tidak mengurangi nilai al-Qur'an, justru di sanalah letak keunikan sekaligus keistimewaannya. Dengan demikian, al-Qur'an menjadi obyek kajian yang tidak pernah kering dari para ilmuan Muslim maupun non Muslim, sehingga ia tetap aktual sejak diturunkan sampai kini. ${ }^{16}$

Al-Qurthûbî meriwayatkan pendapat-pendapat seperti ini adalah pendapat umum, ia juga mengemukakan pendapat Ibn al-'Arabî yang melihat dari sudut teologis dengan

${ }^{14}$ Hermeneutika adalah ilmu yang mencoba menggambarkan bagaimana sebuah atau satu kejadian dalam waktu dan budaya lampau dapat dimengerti dan menjadi bermakna secara eksistensial dalam situasi sekarang. Ini melibatkan aturan metodologis yang diterapkan dalam penafsiran maupun asumsi-asumsi epistimologis tentang pemahaman. Hermeneutika mengasumsikan bahwa setiap orang mendatangi teks dengan membawa persoalan dan harapan sendiri, dan adalah masuk akal untuk menuntut penafsir menyisihkan subjektivitas dirinya dan menafsirkan suatu teks tanpa pemahaman dan pertanyaan awal yang dimunculkannya. Lihat Farid Esack, Membebaskan yang Tertindas: al-Qur'ân, Liberalisme, Pluralisme, terj. Watung A. Budiman (Bandung: Mizan, 2000), h. 83.

${ }^{15}$ Tim Penyusun, Ensiklopedi al-Qur'ân Kajian Kosa Kata dan Tafsirnya (Jakarta: Yayasan Bimantara, 1999), h. 264.

${ }^{16}$ Harifuddin Cawidu, Konsep Kufr dalam al-Qur'ân: Suatu Kajian Teologis dengan Pendekatan Tafsir Tematik (Jakarta: Bulan Bintang, 1991), h. 5. 
mengaitkan konsep tersebut pada sifat-sifat ketuhanan. ${ }^{17}$ Pendapat yang lain dikemukakan oleh al-Aqqâd. Ia mengaitkan ayat tersebut dengan bentuk lahiriah manusia, kemampuan berkehendak dan berbuat, serta keindahan dan kecerdasannya. ${ }^{18}$ Penjelasan yang telah dikemukakan di atas memberi pemahaman bahwa manusia memiliki keunggulan dibandingkan dengan makhluk lain, baik fisik maupun kemampuan intelektual yang dimiliki, memberi kemampuan manusia berusaha untuk memenuhi kebutuhan hidup. Harus didukung dengan prinsip manusia diciptakan dengan memperoleh kemuliaan dan keutamaan dibanding dengan makhluk-makhluk lain.

Secara eksplisit, ayat di atas mengungkapkan bahwa manusia telah diberi kemuliaan (karâmah) dan diciptakan dengan kodrat melebihi makhluk lainnya. Selain itu juga menegaskan karunia Tuhan berupa kemampuan mengarungi lautan dan daratan dan dijadikannya segala yang baik sebagai rezeki bagi manusia. ${ }^{19}$ Dengan begitu, manusia harus dapat bekerjasama untuk menciptakan kedamaian dalam hidup bersama, antara umat manusia.

Kehidupan manusia pada era globalisasi dan teknologi informasi modern yang semakin maju dan menjangkau seluruh lapisan masyarakat, bahkan batas-batas wilayah, maka manusia dihadapkan pada serangkaian tantangan baru seperti bebas mengeluarkan pendapat, keterbukaan dan demokratisasi. Hal tersebut membuktikan bahwa kita telah ditakdirkan hidup dalam suatu bangsa yang masyarakatnya dapat dikatakan sangat pluralistik, bahkan di kalangan bangsa-bangsa lain dinilai sebagai keunikan, penanganannya pun memerlukan keunikan. Pandangan lain dikatakan bahwa pluralisme bukanlah keunikan suatu masyarakat atau bangsa tertentu. Sebab dalam kenyataan, tidak ada suatu masyarakat pun yang benar-benar tunggal, tanpa ada perbedaan di dalamnya.

Kemajemukan sebagai suatu realitas alami, atau dalam bahasa agama disebut sunnah Allâh, tetapi apapun namanya manusia dalam perkembangannya tidak bisa melepaskan diri dari lingkungan pergaulan yang dimungkinkan untuk terjadinya pengaruh, sehingga dapat dilihat manusia telah tererosi oleh perkembangan pemikiran dan kebudayaan, atas nama memenuhi kebutuhan hidup manusia, sebagaimana telah diperingatkan Allah SWT. bahwa telah terjadi kerusakan di darat dan di laut akibat ulah tangan-tangan manusia.

Ketika menjelaskan kata

mufassir banyak menghubungkan dengan penjelasan terhadap surah Yûnus/10: 19, bahwa manusia pada dasarnya hanya satu umat dalam kepercayaan tauhid, tetapi setelah itu tidak lagi demikian, karena mereka berselisih. ${ }^{20}$ Mereka sejak dahulu hingga kini baru dapat hidup jika bantu-membantu

${ }^{17}$ Abû 'Abd Allâh Muhammad bin Aḥmad al-Qurthubî, Al-Jâmi‘ li A $\underline{h} k a ̂ m$ al-Qur'ân, Jilid XX (Mesir: Dâr al-Kâtib al-'Arabiy, 1967), h. 114.

18'Abbâs Mahmûd al-Aqqâd, Al-Insân fî̀ al-Qur'ân (Kairo: Dâr al-Hilâl, t.t.). h. 15.

${ }^{19}$ Abd al-Muin Salim, Fitrah Manusia dalam al-Qur'an (Makassar: Lembaga Studi Kebudayaan Islam, 1990), h. 24.

${ }^{20}$ Muhammad Quraish Shihab, Tafsir al-Mishbah: Pesan, Kesan dan Keserasian al-Qur'an, 
sebagai satu umat, yaitu kelompok yang memiliki persamaan dan keterikatan. ${ }^{21}$ Karenanya manusia harus berlomba-lomba berbuat kebajikan, sebagai tanggung jawab kepada Allah SWT.

Para mufasir Muslim berbeda pendapat mengenai kapan manusia itu pernah mmenjadi umat yang satu. Apakah yang dimaksud umat yang hidup dalam zaman antara Nabi Adam as., dan Nabi Nuh as.? Karena tidak ada indikasi dalam al-Qur'an dan sunnah mengenai waktu bersatunya umat. ${ }^{22}$ Sebagaimana juga disebutkan pada ayat al-Qur'an:

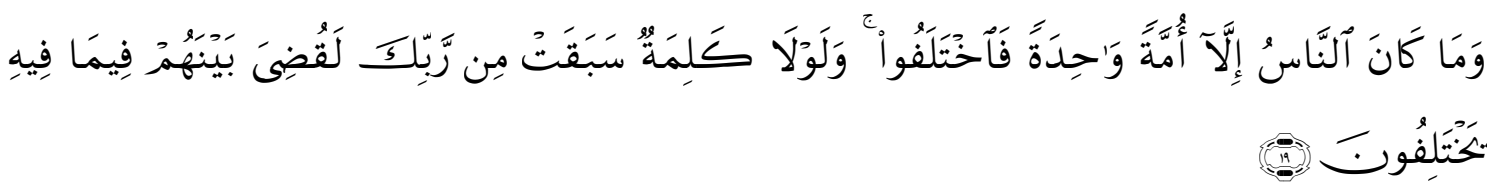

Manusia dahulunya hanyalah satu umat, kemudian mereka berselisih. Kalau tidaklah karena suatu ketetapan yang telah ada dari Tuhanmu dahulu, pastilah telah diberi keputusan di antara mereka, tentang apa yang mereka perselisihkan itu. (Q.S. Yûnus/10: 19).

Pada ayat tersebut, mufasir memahami kata

perbedaan manusia pada 1) perbedaan menyembah Allah SWT. dan menyembah berhala. 2) perbedaan perselisihan pertama antara manusia terjadi dalam kasus kedua putra Adam as. Hâbil dan Qâbil yang membawa pertumpahan darah. ${ }^{23}$ Tetapi, cenderung pada perbedaan pada menyembah Allah SWT. dan yang menyembah berhala, atau mukmin dan kafir.

Vol. I (Jakarta: Lentera Hati, 2002), h. 425, perlu diketahui lebih sungguh-sungguh lagi dalam menghayati tanggung jawab mondial atau prinsip kemanusiaan bersama "satu dunia untuk semua," sehingga keterpecahan hampir menjadi kendala terbesar yang siap menghadang tugas untuk menciptakan era baru bagi sistem dunia yang benar-benar beradab. Dunia yang bergerak serempak menuju tatanan yang saling menghormati dan melindungi, saling membantu dan mendukung, guna terbentuknya "komonitas internasional" yang beradab, adalah dunia yang dirindukan bersama. Said Agil Husein al-Munawwar, Al-Qur'an Membangun Tradisi Kesalehan Hakiki (Jakarta: Ciputat Pers, 2002), h. 372.

${ }^{21}$ Shihab, Tafsir al-Mishbah, Vol. I, h. 425. Kesatuan agama para nabi dan rasul itu, sebagaimana disebutkan dalam al-Qur'an, adalah karena semua berasal dari pesan atau ajaran Allah (QS. alSyûrâ/42: 13). Jadi, sudah seharusnya dihormati keberadaan agama-agama itu tanpa membedabedakannya. Justru perasaan berat untuk bersatu dalam agama itu disebutkan sebagai sikap kaum musyrik, penyembah berhala, sedangkan perbedaan antar berbagai agama itu hanyalah dalam bentuk-bentuk jalan (syir'ah atau syariah) dan cara (manhaj) menempuh jalan itu. Tetapi menjadi pangkal berlomba-lomba menuju kebaikan. Manusia tidak perlu mempersoalkan perbedaan itu. Nurcholish Madjid, Fat Soen (Jakarta: Republika, 2002 M), h. 77.

${ }^{22}$ Sachedina, Kesetaraan Kaum Beriman, h. 50.

${ }^{23}$ Shihab, Tafsir al-Mishbah, Vol. VI, h. 44, sementara tujuan hidup manusia adalah untuk mengabdi kepada Allah atau mengembangkan potensi-potensinya sesuai dengan perintah Allah dengan kemauannya sendiri dan untuk memanfaatkan alam (yang secara otomatis adalah Muslim atau tunduk kepada Allah), ia pun harus mempunyai cara-cara yang memadai untuk memperoleh nafkah dan untuk "menemukan jalan yang benar". Jadi, Tuhan, yang di dalam kelimpahan kasihNya menciptakan alam dan menusia, di dalam kasih-Nya yang tiada berkeputusan itu telah memberikan 
Kenyataan menunjukkan perbedaan pendapat terkadang meruncing sampai pada titik terendah, yaitu terjadinya konflik horizontal antara umat beragama, saling membantai, menjarah dan membakar apa saja yang ditemukan, tidak terkecuali rumah ibadah sekalipun. ${ }^{24}$ Semua itu dilakukan dengan alasan mempertahankan umat masing-masing. Lebih memprihatinkan lagi adalah ajaran suci yang diyakini setiap umat beragama, sebagai nilai yang dapat memberikan kesejahteraan dan kedamaian umat manusia, telah disalahpahami, bahkan telah ditafsirkan sebagai pembenaran terhadap pendirin sikap dan kelakuan umat beragama.

Lihatlah konflik yang terjadi di berbagai daerah khususnya di Maluku, setiap kelompok agama dengan simbol-simbol agama dimanfaatkan untuk menyemangati umatnya masing-masing, mendorong semangat setiap umat untuk melakukan penyerangan, pembantaian bahkan penghancuran apa saja yang ditemuinya, anak-anak, wanita dan orang tua yang tidak berdaya pun harus menjadi korban dari perilaku yang tidak lagi menghargai hak hidup setiap manusia. Sebuah contoh yang tentunya tidak perlu menjadi contoh bagi generasi mendatang, baik di daerah Maluku bahkan di mana pun di bumi ini. Saling menghargai dan melindungi bagi segenap manusia harus ditonjolkan, menjadikan bumi tempat yang damai bagi setiap manusia, bahkan makhluk hidup lainnya.

Al-Qur'an mengakui pluralitas dalam kehidupan manusia dan pluralitas syariat di bawah kesatuan agama yang satu. Al-Qur'an mengisyaratkan perbedaan syariat itu untuk mendapatkan keselamatan dengan prinsip-prinsip, 1) Keimanan kepada Tuhan Yang Maha Esa. 2) Keimanan akan hari akhirat, pembangkitan, hisab dan pembalasan amal baik dan buruk, dan 3) Beramal saleh dalam kehidupan dunia. ${ }^{25}$ Seperti dinyatakan dalam al-Qur'an:

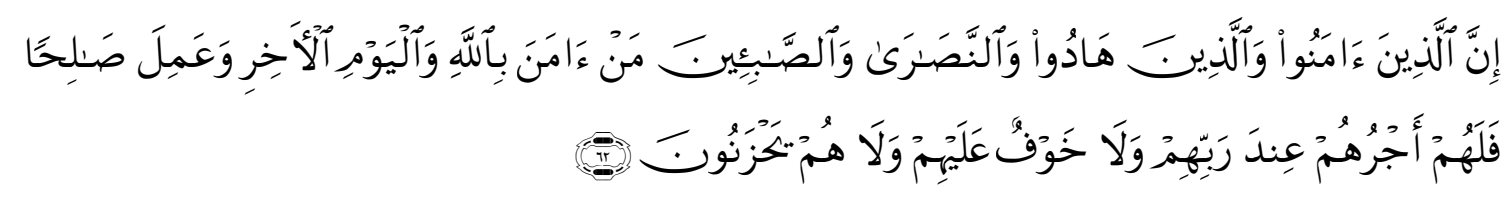

Sesungguhnya orang-orang mukmin, orang-orang Yahudi, orang-orang Nasrani dan orangorang Shâbi'în, siapa saja di antara mereka yang benar-benar beriman kepada Allah, hari kemudian dan beramal saleh, mereka akan menerima pahala dari Tuhan mereka, tidak ada

kepada manusia kesadaran dan kemauan yang diperlukannya untuk memperoleh pengetahuan dan memanfaatkan pengetahuan tersebut untuk menyadari tujuan hidup sesungguhnya. Fazlur Rahman, Tema Pokok al-Qur'an (Bandung: Pustaka, 1996 M), h. 13.

${ }^{24}$ Dapat diamati konflik Maluku, menyebabkan konflik yang sangat multi dimensional sehingga konflik relatif sulit diselesaikan akibat konflik begitu lama yang menyebabkan korban besar, baik korban nyawa maupun harta benda, menyebabkan terjadinya pengungsian besar di tempat yang dianggap aman yang menimbulkan dendam antara dua komunitas yang berhadapan di Maluku dan menjadikan simbol-simbol agama sebagai pemicunya. Lihat Suaidi Marasabessy (ed.), Maluku Baru Satu wujud Ideal Masyarakat Maluku Pasca Konflik (Jakarta: Abadi, 2002), h. 165.

${ }^{25}$ Muhammad 'Imarah, Islam dan Pluralitas Perbedaan dan Kemajemukan dalam Bingkai Persatuan, terj. Abdul Hayyi al-Qattani (Jakarta: Gema Insani Press, 1999), h. 15. 
kekhawatiran terhadap mereka, dan tidak (pula) mereka bersedih hati. (Q.S. al-Baqarah/ 2: 62).

Inti ajaran agama yang disampaikan kepada manusia adalah beriman kepada Allah SWT., walaupun kenyataan manusia berbeda-beda dalam agama-agama yang dibawa oleh para nabi utusan Allah SWT. bagaimana membuat manusia beriman dengan mengalihkan perhatiannya kepada berbagai fakta yang ada di sekelilingnya bahkan mengubah fakta-fakta menjadi sesuatu yang lebih mendekatkan manusia kepada Allah SWT. untuk mendapatkan kedamaian dan keselamatan, baik dunia dalam hubungan manusia sesama, maupun di akhirat sebagai tanggungjawab yang dijalaninya. Pada ayat yang lain seperti dinyatakan dalam ayat:

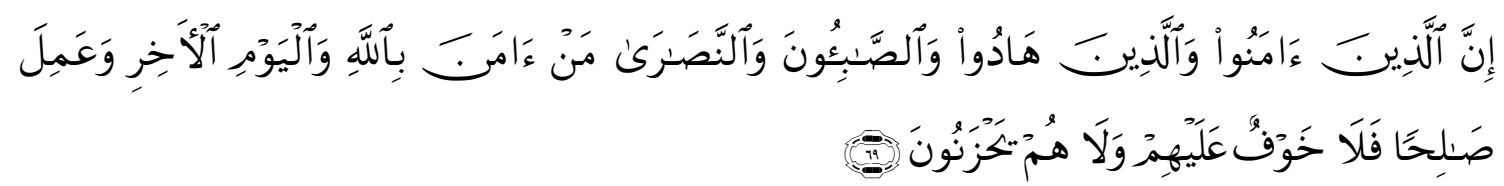

Sesungguhnya orang-orang mukmin, orang-orang Yahudi, Shabi'in dan orang-orang Nasrani, siapa saja (di antara mereka) yang benar-benar beriman kepada Allah, hari kemudian dan beramal saleh, maka tidak ada kekhawatiran terhadap mereka dan tidak (pula) mereka bersedih hati (Q.S. al-Mâ'idah/5: 69).

Ayat-ayat di atas telah memberi pemahaman bahwa Allah memberi jalan keluar sekaligus ketenangan kepada mereka yang bermaksud memperbaiki diri. Ini sejalan dengan kemurahan Allah yang senantiasa membuka pintu bagi hamba-hamba-Nya yang sadar akan kesalahan dan mau memperbaiki diri tentang keimanan dan amal saleh. ${ }^{26}$ Bahkan mereka menyatakan bahwa tidak akan masuk surga kecuali kelompok beriman: Islam, Yahudi dan Nasrani. ${ }^{27}$ Dengan ketentuan beriman kepada Allah, hari kemudian dan beramal saleh. Sebagaimana juga dinyatakan dalam al-Qur'an:

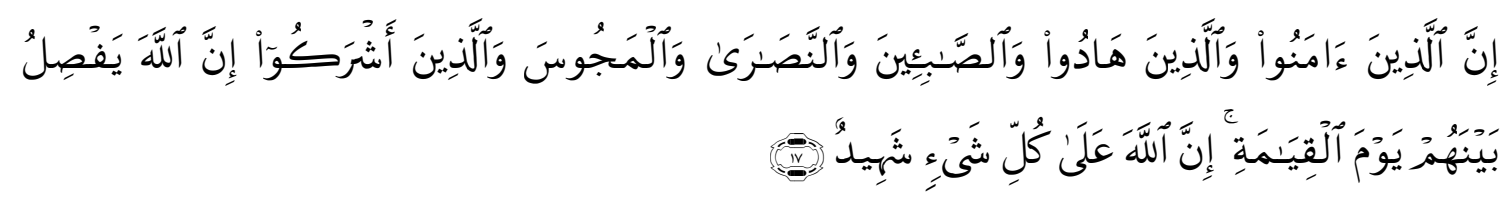

Sesungguhnya orang-orang beriman, orang-orang Yahudi, orang-orang Shâbi'în, orangorang Nasrani, orang-orang Majusi dan orang-orang musyrik, Allah akan memberi keputusan di antara mereka pada hari kiamat. Sesungguhnya Allah menyaksikan segala sesuatu (Q.S. al-

${ }^{26}$ Muhammad Husain al-Thabâthabâ̂̂̂, al-Mîzan fî Tafsîr al-Qur'ân, Jilid I (Beirut: alMujillah, 1991 M), h. 192

${ }^{27}$ Ibid. 
Ketiga ayat tersebut di atas satu sama lain saling mendukung, dan pada dasarnya memiliki penafsiran yang secara substansial sama, walaupun tampak ada perbedaan. Bahwa kehidupan pluralitas dan saling menghargai sesama telah merupakan pengakuan al-Qur'an. Walaupun tidak dapat dimungkiri bahwa dalam memahami ayat-ayat tertentu cenderung anti pluralisme. Suatu realitas masyarakat hari ini, tetapi dalam perkembangan selanjutnya akan ada sebuah perubahan ketika sumberdaya manusia telah tertangani dengan baik, akan melahirkan suatu kondisi hidup yang lebih menghargai martabat dan kesempatan hidup bagi setiap manusia.

Al-Qur'an menyebutkan agama-agama selain Islam ${ }^{28}$ seperti Yahudi dan Nasrani. Hal itu menandakan adanya pengakuan pluralisme agama. Dari pandangan tersebut, maka melalui kajian ini akan dirumuskan dengan jalan mengadakan pelacakan terhadap ayat-ayat yang berkaitan dengan makna pluralisme agama. Karena mereka berbeda, maka Allah menciptakan manusia. ${ }^{29} \mathrm{Al}$-Gazâlî menyatakan bahwa bagaimana manusia dapat bersatu untuk mendengarkan yang satu saja, manusia telah ditetapkan pada masa azali bahwa manusia akan terus berbeda-beda, kecuali orang-orang yang dikasihi Allah SWT. dan karena berbeda-beda itu pula manusia diciptakan. ${ }^{30}$ Jika pluralisme agama merupakan faktor yang membuahkan perbedaan, maka makna dari teks al-Qur'an perlu dipahami lebih dalam lagi. ${ }^{31}$ Faktor kesatuan kemanusiaan menjadi sesuatu yang mengikat manusia, karena ada kemungkinan berbeda-beda karena latar belakang kelahiran, tetapi tidak berbeda dalam batin.

\section{Mengapa Pluralisme Agama}

Sebagaimana telah dikemukakan, pluralisme berasal dari kata 'plural' yang bermakna 'banyak' atau 'lebih dari satu.' Dengan demikian, pluralisme berarti menyatakan hal yang

${ }^{28}$ Hakikat sikap al-Qur'an ketika pluralitas menjadi kemajemukan dalam kerangka kesatuan adalah sunnah Allah, telah difitrahkan bagi sekalian manusia. Allah menjadikan berbeda-beda dalam bentuk fisik, pemikiran dan amal mereka, setiap jari yang berbeda-beda dalam kerangka kesatuan manusia. Karena mereka berbeda, maka Allah menciptakan mereka. Lihat Tantawi Jauhari, al-Jawâhir fì Tafsîr al-Qur'ân (Kairo: Dâr al-Fikr, t.t.), h. 33-34.

${ }^{29}$ Al-Qurthubî, Al-Jâmi‘ li Ahkâm al-Qur'ân, Jilid IX, h. 115.

${ }^{30}$ Imarah, Islam dan Pluralitas, h. 35.

${ }^{31}$ Sudah menjadi karakteristik al-Qur'an dalam membicarakan obyek tertentu, yakni banyak membicarakan secara global. Ada yang berkaitan dengan perbedaan obyek dalam satu tempat (ayat atau surah) dan ada yang tampak tidak runtut. Karena itu, Shihab menyatakan alQur'an tidak bisa disamakan dengan kitab-kitab yang disusun secara sistimatis menurut penilaian metode ilmiah. Tidak sistimatisnya pembicaraan al-Qur'an, memberikan kesan bahwa ajaranajaran dan hukum-hukum yang terkandung di dalamnya merupakan satu kesatuan yang harus ditaati oleh penganut-penganutnya secara keseluruhan tanpa ada pemisahan antara yang satu dengan yang lainnya. Muhammad Quraish Shihab, Membumikan al-Qur'an (Bandung: Mizan, 1992), h. 34. 
banyak atau lebih dari satu. ${ }^{32}$ Dalam kajian filosofis, pluralisme diberi makna sebagai doktrin, bahwa substansi hakiki itu tidak satu (monisme), tidak dua (dualisme), akan tetapi banyak (jama'). ${ }^{33}$

Dalam the Oxford English Dictionary disebutkan, pluralisme dapat dipahami sebagai berikut. Pertama, suatu teori yang menentang kekuasaan negara monolistis. Sebaliknya, mendukung desentralisasi dan otonomi untuk semua unsur utama yang mewakili individu dalam masyarakat. Juga suatu keyakinan bahwa kekuasaan itu harus dibagi bersama-sama oleh setiap kelompok. Kedua, keberadaan atau toleransi keragaman etnik atau kelompokkelompok kultural dalam suatu masyarakat dan negara, serta keragaman kepercayaan atau sikap dalam suatu badan, kelembagaan dan lainnya harus terakomodasi dalam dinamika sosial. ${ }^{34}$ Karena manusia diciptakan Tuhan untuk saling berinteraksi satu dengan lainnya, termasuk dalam umat berbeda pandangan dan bahkan berbeda agama.

Mengenai pluralisme dalam tradisi Islam, yang dimaksud menunjuk kepada wahyu agama Ibrahimi termuda ini sebenarnya bisa mengungkapkan diri dalam suatu dunia agama pluralistis. Islam mengakui dan menilainya secara kritis, tetapi tidak pernah menolaknya atau menganggapnya salah. Malah, ruang spiritual al-Qur'an sebagaimana akan ditunjuk, juga dimiliki oleh agama monoteistik lainnya. Tugas utama yang dihadapi oleh umat Islam awal adalah melindungi identitas anggotanya dalam pandangan teosentris (berpusat pada Tuhan) yang juga dimiliki oleh tradisi lain. ${ }^{35}$

Tanja menulis bahwa kitab suci Kristen secara keseluruhan banyak sekali berkatakata tentang etnisitas dan religiositas yang menempatkan kedua istilah itu dalam pengertian yang saling berkaitan. Dalam Perjanjian Lama, umpamanya, ada istilah Goyyim yang berarti bangsa-bangsa yang bukan bangsa Israel yang dikatakan sebagai am Yahweh (bangsa pilihan Allah). Bangsa-bangsa ini mempunyai agama masing-masing. Namun, karena agama mereka hanya untuk agama mereka saja, maka mereka disebut sebagai bangsa kafir. Jadi,

32Jhon M. Echols dan Hassan Shadily, Kamus Inggris Indonesia (Jakarta: Gramedia, 1984), h. 435.

${ }^{33}$ Encyclopedia Americana, Jilid XXII, h. 258.

${ }^{34} \mathrm{Di}$ berbagai belahan dunia, toleransi merupakan kata kunci yang senantiasa menjadi isu yang perlu mendapat perhatian, tetapi dalam realitas masyarakat, hubungan ras dan agama masih belum terselesaikan, bahkan pada kawasan tertentu hal ini semakin meningkat intensitas konflik bahkan peperangan.

${ }^{35}$ Apakah harapan adanya keberagamaan pluralis, harapan adanya satu pengakuan terhadap perbedaan spiritual merupakan konsekuensi tidak disengaja dari terus meningkatnya kesalingtergantungan ekonomi dan teknologi, yang juga kaum lain menjadi semakin terbuka dan mendekat?. Atau apakah harapan akan adanya rekonsiliasi ini bagian warisan manusia yang sudah mendarah-daging (long-germinating), suatu warisan yang diawetkan dalam wacana religius klasik yang harus berurusan dengan berbagai klaim bertentangan mengenai hak eksklusif penyelamatan, baik dalam konteks sesama umat beragama sama?. Sachedina, Kesetaraan Kaum Beriman, h. 49-50. 
dalam konteks pengertian ini, bangsa kafir bukanlah bangsa yang tidak beragama. Mereka beragama, tetapi bagi bangsa mereka saja dan bukan bangsa lain. ${ }^{36}$

Sejak lahirnya ajaran Leibniz yang ketika mempertanyakan tentang fisika. Aada berapa substansi itu? Ia menjawab 'banyak'. Jawaban inilah yang menjadikan Leibniz seorang pluralis. ${ }^{37}$ Ajaran Herbart tentang banyak hal yang terjadi dalam diri sendiri, dan teori James tentang Pragmatisme, ${ }^{38}$ dan dalam pendekaan sosiologis pluralisme dapat dipahami sebagai sistem nasional dalam suatu negara yang hidup sebagai kelompok etnis, agama, kultural, status sosial.

Dengan demikian, pluralisme dapat dipahami dan diidentifikasi dengan hal-hal sebagai berikut. Pertama, selalu berkaitan dengan memelihara dan menjunjung tinggi hak dan kewajiban ${ }^{39}$ masing-masing kelompok, dalam berbagai bentuk strata sosial, agar dapat berperan sebagaimana yang dapat mereka laksanakan dalam bentuk kewajiban dan tanggung jawab bersama sebagai makhluk Tuhan. Kedua, menghargai perbedaan dalam kebersamaan masyarakat yang benar-benar memiliki karakteristik plural dan meyakini bahwa setiap pihak berada dalam posisi yang sama secara positif. Mereka meyakini bahwa tidak ada kelompok masyarakat yang lebih unggul dari kelompok lain dalam berbagai hal. Sebagai warga masyarakat mereka mempunyai hak, kedudukan, kewajiban dan tanggungjawab yang sama. Perbedaan tidak dipahami sebagai ancaman terhadap eksistensi suatu kelompok. Ketiga, pluralisme menunjukkan kepada wahana untuk mengembangkan dan meningkatkan kemampuan berkompetisi secara jujur, terbuka dan adil. Karakteristik ini berkaitan dengan upaya menghilangkan pendapat, bahwa dalam kehidupan masyarakat ada kelompok ordinate yang mendominasi kelompok subordinate, kelompok mayoritas merasa lebih unggul dari kelompok minoritas. Keempat,

${ }^{36}$ Victor I. Tanja, Atas Nama Agama: Wacana Agama dalam Dialog "Bebas" Konflik (Bandung: Pustaka Hidaya, 1998), h. 75.

${ }^{37}$ Nama lengkap Leibniz adalah Gottfried Wilhelm Von Leibniz, lahir pada tahun 1656 dan meninggal pada tahun 1716, filosof, matematikawan, fisikawan dan sejarawan. Ia menjadi pegawai pemerintah, menjadi atase, dan pembantu pejabat tinggi negara. Ahmad Tafsir, Filsafat Umum Akal dan Hati Sejak Thales sampai James (Bandung: Remaja Rosdakarya, 1990), h. 122.

${ }^{38}$ William James (1842-1910) adalah tokoh yang paling bertanggung jawab yang membuat pragmatisme menjadi terkenal di seluruh dunia. Lebih dari itu, ia merupakan orang Amerika pertama yang memberikan kontribusi kedalam gelombang dahsyat pemikiran filsafat di dunia Barat, karena terbit bukunya Pragmatisme (1907) dan The Meaning of Truth (1909), gerakan pragmatisme meluncur seolah-olah akan menguasai filsafat abad ke-20, ia telah mengubah pragmatisme menjadi filsafat hidup, Filsafat pada dasarnya merupakan filsapat untuk bertindak. Ibid., h. 167.

${ }^{39} \mathrm{Hak}$ dan kewajiban dimaksudkan, semua warga negara, sebagai individu dan sebagai anggota dari kelompok dan lembaga yang berbeda, harus menerima kewajiban untuk mengenali dan membantu melindungi hak orang lain. Hak harus disertai tanggung jawab, kecenderungan untuk menegaskan hak dengan melupakan tanggung jawab menimbulkan akibat yang mengganggu. Dalam jangka panjang, hak hanya dapat dilindungi jika dilaksanakan secara bertanggung jawab dan menghormati orang lain. Komisi Pemerintahan Global, Kerukunan Dunia (Jakarta: Balai Pustaka, 1997), h. 70. 
pluralisme harus didudukkan pada posisi yang proporsional. Perbedaan menjadi daya dorong untuk mendinamisasi kehidupan masyarakat, dan bukan mekanisme untuk menghancurkan satu kelompok terhadap kelompok lain. Pluralisme ada pada posisi yang netral, tidak memihak dan obyektif. Kelima, pluralisme menunjukkan adanya perasaan kepemilikan bersama, untuk kepentingan bersama dan diupayakan bersama. Karakteristik semacam ini pada hakikatnya merupakan puncak dari kesadaran bahwa pluralisme merupakan menifestasi jati diri manusia.

Pluralisme diibaratkan mozaik dan tata warna yang indah dalam sebuah lukisan atau kelompok paduan suara secara bersama menyanyikan sebuah lagu dalam bentuk simponi yang indah didengar dan dipandang. Begitu pula pluralisme agama, yang kalau dapat dirinci sesuai dengan yang disebutkan di dalam al-Qur'an adalah, orang-orang beriman, orang-orang Yahudi, orang-orang Nasrani, orang-orang Shâbi'in, orang-orang Majusi dan orang-orang Musyrik. Hidup bersama menghuni bumi untuk kepentingan bersama dan berdasarkan kepentingan kemanusiaan.

Karena, manusia beriman adalah bersaudara sebagaimana disimpulkan oleh Cak Nur seperti berikut. 1) Semua orang yang beriman adalah saudara satu dengan lainnya. 2) Namun kaum beriman itu tidaklah semuanya sama dalam segala hal. Adanya perbedaan mungkin saja menimbulkan pertikaian, yang harus selalu diusahakan pendampingnya. 3) Perdamaian antara dua kelompok yang bertikai itu adalah dalam rangka takwa kepada Allah. 4) Dengan takwa itu Allah akan menganugerahkan rahmat-Nya yang mendasari jiwa persaudaraan. 5) Maka harus ada sikap saling menghormati, dengan tidak merendahkan suatu golongan lain. 6) Setiap golongan harus cukup rendah hati untuk mengakui kemungkinan diri mereka salah, dan golongan lain benar. 7) Sejalan dengan itu dilarang saling menghina sesama kaum beriman. 8) Juga dilarang memberi nama ejekan satu sama lain, apalagi jika ejekan kejahatan. 9) Yang tidak mengikuti itu semua adalah orang-orang zalim. 10) Kaum beriman harus menjauhkan banyak prasangka, karena itu bisa jahat. 11) Juga dilarang saling mencari kesalahan. 12) Dilarang pula melakukan pengumpatan (ghîbah, beck bitting), yaitu membicarakan keburukan sesama ketika yang dibicarakan itu tidak ada di tempat pembicaraan. 13) Melakukan gîbah itu bagaikan memakan daging mayat saudara sendiri, sebab orang yang dibicarakan keburukannya itu, karena tidak di tempat, tidak dapat membela diri, apalagi melawan. Jadi, ghîbah adalah kejahatan ganda, suatu kejahatan di atas kejahatan. 14) Sekali lagi manusia beriman diseru untuk bertakwa kepada Allah, yaitu menyadari akan ada pengawasan Allah yang selalu hadir di mana pun seseorang berada, sehingga tidak sepatutnyalah seorang yang beriman melakukan sesuatu yang tidak diperkenankan oleh-Nya. 15) Takwa kepada Allah menghasilkan bimbingan ke arah budi pekerti yang luhur itu, maka Allah akan mengampuni manusia dan memberi rahmat-Nya kepadanya. 16) Lebih lanjut, kita diingatkan bahwa seluruh umat manusia pun diciptakan Allah berbeda-beda, karena dijadikan oleh-Nya berbangsabangsa dan bersuku-suku. 17) Itu semua tidak lain ialah agar kita saling kenal dengan 
sikap saling menghormati (arti luas dari perkataan Arab ta'âruf). 18) Manusia tidak boleh membagi manusia menjadi tinggi rendah karena pertimbangan-pertimbangan askripitif atau kenisbatan, seperti kebangsaan, kesukuan, dan lain-lain. 19) Sebab dalam pandangan Allah, manusia tinggi dan rendah hanyalah berdasarkan tingkat ketakwaan yang telah diperolehnya. 20) Manusia tidak akan mengetahui dan tidak diperkenankan menilai atau mengukur tingkat ketakwaan sesamanya itu. ${ }^{40}$ Agama mengandung arti ikatan-ikatan yang harus dipegang dan dipatuhi manusia. Ikatan ini mempunyai pengaruh yang besar terhadap kehidupan manusia sehari-hari. Ikatan itu berasal dari suatu kekuatan yang lebih tinggi dari manusia. Satu kekuatan gaib yang tidak dapat ditangkap dengan pancaindra. ${ }^{41}$ Agama sebagaimana diketahui lebih banyak berhubungan dengan hati (iman) ketimbang rasio walau pernyataan ini masih menjadi perdebatan. Agama mengandung demensi subyektivitas, dalam arti pengalaman keagamaan perindividu yang sulit ditelusuri dalam arti tingkat keimanan seseorang hanya Tuhanlah yang tahu kadar keimanan seseorang, karena manusia sering goyah dalam hidup.

\section{Penutup}

Al-Qur'an adalah kitab petunjuk dan rahmat bagi seluruh hamba Allah SWT. Terutama orang-orang Islam yang beriman, karenanya ia harus dijelaskan, dan dioperasionalkan, agar dapat dipahami oleh manusia di berbagai tingkat dan latar belakang sosiokulturnya.

Al-Qur'an menginformasikan bahwa pluralisme agama merupakan suatu yang alami (sunnah Allâh), dan dengan pluralisme manusia diciptakan, bahkan jika Tuhan menghendaki, tentu Dia menjadikan manusia umat yang satu, tetapi mereka senantiasa berselisih pendapat, dan berselisih pendapat adalah rahmat. Dengan memahami konsep pluralisme agama sebagaimana yang dikehendaki oleh ayat-ayat al-Qur'an, dapat diduga setiap Muslim dalam pergaulan keseharian dapat mengamalkan dalam pergaulan dengan kelompok manusia yang lain, baik agama, suku bahkan pergaulan antar bangsa.

Pluralisme agama yang dimaksud al-Qur'an, bukan saja untuk memberikan kahidupan yang layak intern umat Islam, tetapi lebih dari itu memberikan semangat hidup berdampingan dengan umat lainnya, baik dalam kehidupan keagamaan maupun dalam kehidupan kebangsaan dan antar bangsa. Para nabi dan agama-agama sebelumnya juga datangnya dari Tuhan Yang Maha Kuasa dan Maha Pemberi kepada para hamba-hamba-Nya.

\section{Pustaka Acuan}

Al-'Aqqâd, 'Abbâs Mahmûd. Al-Insân fí al-Qur'ân. Kairo: Dâr al-Hilâl. t.t.

\footnotetext{
${ }^{40}$ Nurcholish Madjid, Masyarakat Religius: Membumikan Nilai-nilai Islam dalam Kehidupan Masyarakat (Jakarta: Paramadina, 2000), h. 31-32.

${ }^{41}$ Harun Nasution, Islam Ditinjau dari Berbagai Aspeknya (Jakarta: UI-Press, 1985), h. 10.
} 
MIQOT Vol. XXXVI No. 2 Juli-Desember 2012

Cawidu, Harifuddin. Konsep Kufr dalam al-Qur'ân: Suatu Kajian Teologis dengan Pendekatan Tafsir Tematik. Jakarta: Bulan Bintang. 1991.

Depdiknas. Kamus Besar Bahasa Indonesia. Jakarta: Balai Pustaka. 1990.

Ensiklopedi Indonesia. Vol. V. Jakarta: Ichtiar Baru Van Hoeve. 1984.

Encyclopedia Americana. Jilid XXII. Philippines: Copy right. 1972.

Esack, Farid. Membebaskan yang Tertindas: al-Qur'ân. Liberalisme. Pluralisme. terj. Watung A. Budiman. Bandung: Mizan. 2000.

Echols, Jhon M. dan Hassan Shadily. Kamus Inggris Indonesia. Jakarta: Gramedia. 1984.

'Imarah, Muhammad. Islam dan Pluralitas Perbedaan dan Kemajemukan dalam Bingkai Persatuan. terj. Abdul Hayyi al-Qattani. Jakarta: Gema Insani Press. 1999.

Jauhari, Tantawi. al-Jawâhir fî Tafsîr al-Qur'ân. Kairo: Dâr al-Fikr. t.t.

Komisi Pemerintahan Global. Kerukunan Dunia. Jakarta: Balai Pustaka. 1997.

Madjid, Nurcholish. Islam Doktrin dan Peradaban. Jakarta: Yayasan Wakaf Paramadina. 1992.

Marasabessy, Suaidi (ed.). Maluku Baru Satu wujud Ideal Masyarakat Maluku Pasca Konflik. Jakarta: Abadi. 2002.

Al-Munawwar, Said Agil Husein. Al-Qur'an Membangun Tradisi Kesalehan Hakiki. Jakarta: Ciputat Pers. 2002.

Madjid, Nurcholish. Fat Soen. Jakarta: Republika. 2002 M.

Madjid, Nurcholish. Masyarakat Religius: Membumikan Nilai-nilai Islam dalam Kehidupan Masyarakat. Jakarta: Paramadina. 2000.

Nasution, Harun. Islam Ditinjau dari Berbagai Aspeknya. Jakarta: UI-Press. 1985.

Al-Qurthubî, Abû 'Abd Allâh Muhammad bin Ahmad. Al-Jâmi'li Ahkkâm al-Qur'ân. Jilid XX. Mesir: Dâr al-Kâtib al-Arabiy. 1967.

Rahman, Fazlur. Tema Pokok al-Qur'an. Bandung: Pustaka. 1996.

Sachedina, Abdulaziz. Kesetaraan Kaum Beriman: Akar Pluralisme Demokratis dalam Islam. terj. Satrio Wahono. Jakarta: Serambi Ilmu Semesta. 2002.

Salim, 'Abd al-Muin. Fitrah Manusia dalam al-Qur'an. Makassar: Lembaga Studi Kebudayaan Islam. 1990.

Shihab, M. Quraish. et al. Atas Nama Agama Wacana Agama dalam Dialog Bebas Konflik. Bandung: Pustaka Hidayah. 1998.

Shihab, Muhammad Quraish. Tafsir al-Mishbah: Pesan. Kesan dan Keserasian al-Qur'an. Vol. I. Jakarta: Lentera Hati. 2002.

Shihab, Alwi. Islam Inklusif Menuju Sikap Terbuka dalam Beragama. Bandung: Mizan. 2001.

Tanja, Victor I.. Atas Nama Agama: Wacana Agama dalam Dialog “Bebas” Konflik. Bandung: Pustaka Hidayah. 1998.

Tim Penyusun. Ensiklopedi al-Qur'ân Kajian Kosa Kata dan Tafsirnya. Jakarta: Yayasan Bimantara. 1999. 
Abd. Rahman I. Marasabessy: Al-Qur'an dan Pluralitas

Al-Thabâthabâ'î, Muhammad Husain. al-Mîzân fî Tafsîr al-Qur'ân. Jilid I. Beirut: alMujillah. 1991. 